ACTA AGROBOTANICA

Vol. 59, z. 12006

s. 1728

\title{
Morphology, anatomy and ultrastructure of yarrow (Achillea millefolium L.) floral nectaries
}

\author{
ANETA SULBORSKA, \\ ELŻBIETA WERYSZKO-CHMIELEWSKA
}

\author{
Department of Botany, Agricultural University in Lublin \\ ul. Akademicka 15, 20950 Lublin
}

(Received: 3.12.2005)

\section{Su m m ary}

The studies focused on the morphological and anatomical features as well as those related to the ultrastructure of nectary cells Achillea millefolium Asteraceae family. The nectary presence was confirmed only in the disk flowers at the pistil style base. The micromorphology of nectaries was investigated in SEM, and structure was observed in a light and transmission electron microscopes. A number of layers composing a gland, the size and shape of epidermal and glandular cells were determined. The secretory cell ultrastructure was analyzed. The discoidal nectary gland observed from above had a pentagonal shape, 181.5 $\mu \mathrm{m}$ height and $299.4 \mu \mathrm{m}$ diameter. It was built of the monolayer epidermis and 6 layers of the secretory cells on average. The glandular cells appeared to be bigger $(27 \mu \mathrm{m})$ than the epidermal cells $(22 \mu \mathrm{m})$, a cell shape in both tissues differed as well. The nectar secretion occured through the modified stomata. The stomata cells were at distinguishable greater size and raised above the surface of epidermis. The nectaries were supplied by the vascular bundles running from the pistil style up to the nectary base, not getting into the gland. In the cells of the nectary epidermis observed in TEM the big cell nuclei, numerous plastids, mitochondria and vacuoles with fibrous secretion deposits and vesicular structures were found. In the cells of the nectary secretory tissue there were dense cytoplasm, many plastids, mitochondria, Golgi bodies and the extensive network of the endoplasmic reticulum. 


\section{INTRODUCTION}

The yarrow (Achillea millefolium L.), Asteraceae, a medicinal plant known from antiquity, is a strongly aromatic perennial plant found on baulks, dry pastures and roadsides. Entomophilous head inflorescences of the yarrow are made up of white ray flowers and créme disk flowers.

Information on the structure of nectaries in the Asteraceae is very scarce. It relates to the structure of these parts of flowers in only several species from the Centaurea genus (Guly ás and P e st i, 1966), in Helianthus annuus (S a m mataro et al., 1985) and Silphium perfoliatum (W ró b le w s k a, 1997). J a bło ń s k i (1998) states that nectaries in representatives of the Asteraceae are completely hidden, but they are located not very deep in hemitropous flowers. According to the division proposed by S met s (1986), the nectar-secreting glands in the Asteraceae are classified as persistent ("persistentia"), discoid nectaries, attached to the persistent parts of the flower, which include the pistil, whereas according to Fahn's classification (1952), they belong to the group of style nectaries.

The position and structure of nectaries are considered to be taxonomic features of plants. The nectaries of the Asteraceae hitherto studied clearly differ in the size, shape and features of the anatomical structure. So far, no data has been presented relating to the ultrastructure of nectary tissue cells occurring in flowers of Asteraceae plants. There is no information on the structure of the Achillea millefolium nectaries, therefore, an attempt was made to fill in the gaps in this area. Investigations relating to the micromorphology, anatomy and ultrastructure of the nectaries were carried out.

\section{MATERIAL AND METHODS}

The studied plants Achillea millefolium L. came from the collection of the Department of Vegetable Growing and Medicinal Plants at the Agricultural University of Lublin.

The location of the nectaries in the floret was determined. The diameter and height of the gland, the height of the epidermal cells and the longer diameter of the secretory cells were measured, as well as the number of layers of cells making up the nectary tissue was determined. The measurements were made in 10 disk flowers. Features of the ultrastructure of the secretory cells were analysed. Preliminary observations of the nectaries were made in the Olympus SZX-1 stereoscope microscope.

A scanning electron microscopy (SEM) was used for the examination of the surface of the nectaries. Disk flowers with nectaries were fixed in $4 \%$ glutar aldehyde in $0.1 \mathrm{M}$ phosphate buffer ( $\mathrm{pH}$ 7.0) for 4 hours at room temperature. The material was then dehydrated in ethanol series and acetone and dried at critical point with liquid $\mathrm{CO}_{2}$ by using Bal-Tec CPD 030, and coated with gold and platinum by using the Polaron SC 7640 sputter coater. Observations and photos were made in the scanning electron microscope BS 301 with the Tescan attachment for digital processing of microscope imaging. 
For the anatomical analysis of the nectaries, half-thin preparations (the thickness of sections $0.5 \mathrm{~mm}$ ) from the longitudinal sections of tube flower fragments were used. They were stained with $1 \%$ methylene blue with $1 \%$ azur II in a $1 \%$ aqueous solution of sodium tetraborate. The material was fixed and immersed in synthetic resin in accordance with the method applied to the transmission electron microscope. Observations and photos were made by using the Jenaval Kontrast microscope, as well as Eclipse 400, Nikon.

For the ultrastructural examination, the nectaries were fixed in $2 \%$ paraformaldehyde and $2.5 \%$ glutar aldehyde in $0.1 \mathrm{M}$ cacodylate buffer with $\mathrm{pH} 7.4$ at room temperature for 2 hours, and then for 12 hours at temp. $4^{\circ} \mathrm{C}$. After the washing of the specimens for 24 hours in $0.1 \mathrm{M}$ cacodylate buffer at temp. $4^{\circ} \mathrm{C}$ and postfixing them in $1 \% \mathrm{OsO}_{4}$, they were transferred to redistilled water and stained in a $0.5 \%$ aqueous solution of uranyl acetate. In the next stage, the material was dehydrated in an alcohol series (ethanol) and through increasing concentrations of propylene oxide in alcohol, moving to pure propylene oxide. The specimens were immersed in Spurr Low Viscosity resin for 12 hours at temp. $70^{\circ} \mathrm{C}$. The material so prepared was cut into $60 \mathrm{~nm}$ thick sections by using the Reichert Ultracut $\mathrm{S}$ ultramicrotome. Ultrathin preparations were then treated with an $8 \%$ solution of uranyl acetate in $0.5 \%$ acetic acid and lead citrate. Observations of the secretory cells of the nectaries and documentation were made by using the BS-500 Tesla transmission electron microscope (TEM).

\section{RESULTS}

In the yarrow, small head inflorescences comprised 5-6 ray flowers and 12-24 disk flowers (Figs 1, 2). In the species studied, nectaries occurred only in the disk flowers (Fig. 3). Automorphic, discoid nectaries were situated at the bottom of the corolla tube above the lower ovary, partly surrounding the base of the pistil style (Figs $4,5)$. The outer walls of the nectaries, watched from above, had the shape of a pentagon (Fig. 6). Results of the measurements concerning the height and diameter of the nectaries are presented in Table 1.

A comparison of the size of the nectary and the flower's corolla shows that the height of the nectary gland accounted for $8 \%$ of the corolla length and, at the same time, $1 /{ }_{8}$ of the length of the corolla tube. The nectary had a flattened shape, and its diameter was 1.6 of the height (Tab. 1).

The Achillea millefolium nectaries were made of single-layered epidermis and several layers of glandular cells clearly distinguished from the adjacent parenchymal cells by their smaller size and the thicker, more strongly stained cytoplasm (Fig. 5). In the longitudinal section, the variously shaped epidermis cells of the nectary were densely arranged, forming a regular row. The secretory cells were slightly elongated and had polygonal shapes. The abovementioned features and a relatively compact arrangement of the cells made the secretory tissue of the nectary similar to the meristematic tissue (Tab. 1). In the lower part of the nectary gland, there were tightly packed cells, whereas in the subepidermal layers small intercellular spaces were observed. The measurements of the height of the epidermis cells and of the longer diameter of the secretory cells 

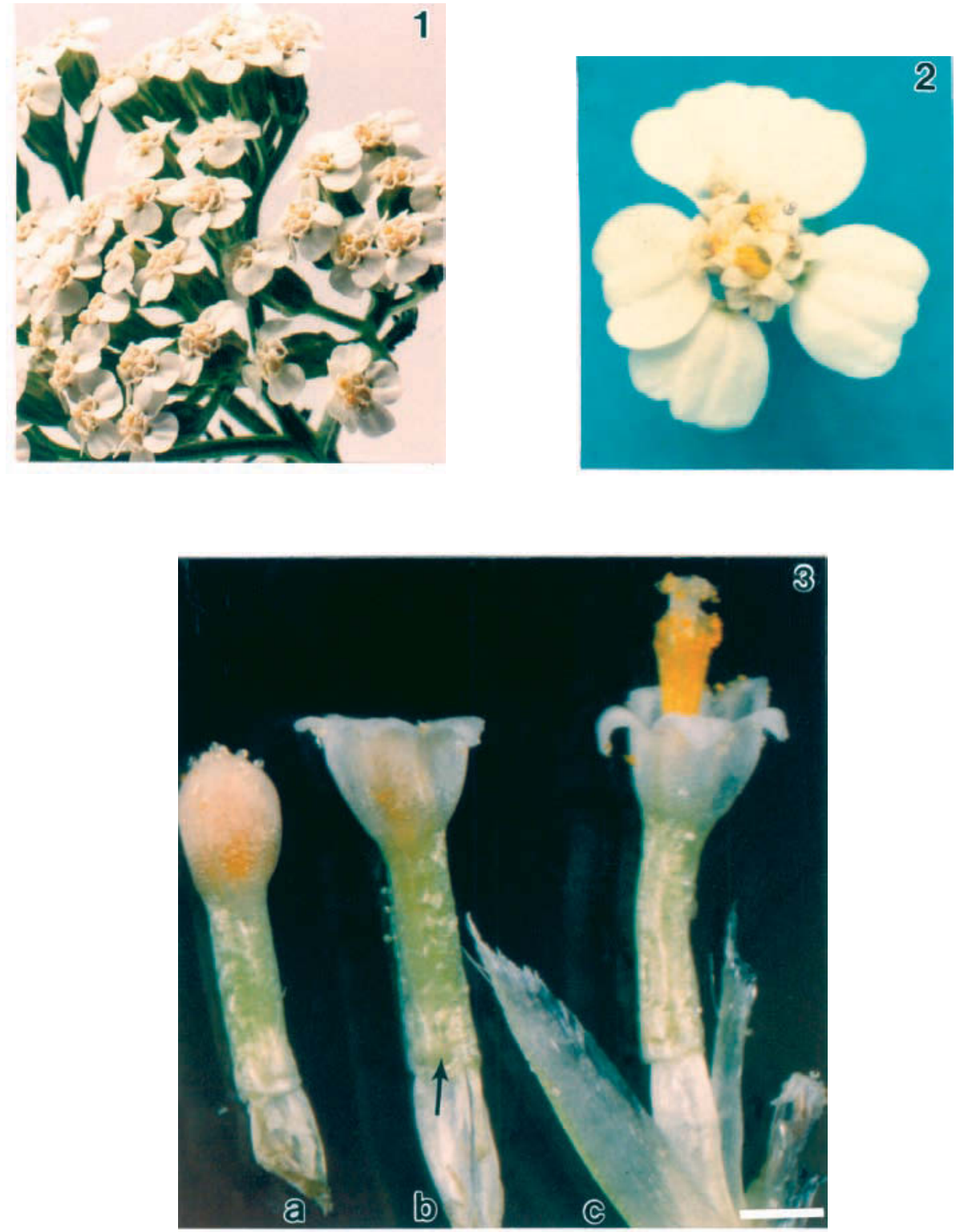

Figs 1 3. Morphology of the head inflorescences and flowers of Achillea millefolium.

Fig. 1. Habit of the inflorescence.

Fig. 2. Anthodium during flowering.

Fig. 3. Tubular florets in different phases of anthesis (a c). Arrow shows location of the nectary, bar $=0,5 \mathrm{~mm}$. 
demonstrate that the latter were characterised by larger dimensions (Tab. 1). No vascular bundles were observed in the glandular tissue area, the nectary was supplied by phloem and xylem elements of the bundle running in the style of the pistil. Branches of these bundles reached the basal part of the nectariferous tissue (Fig. 5).
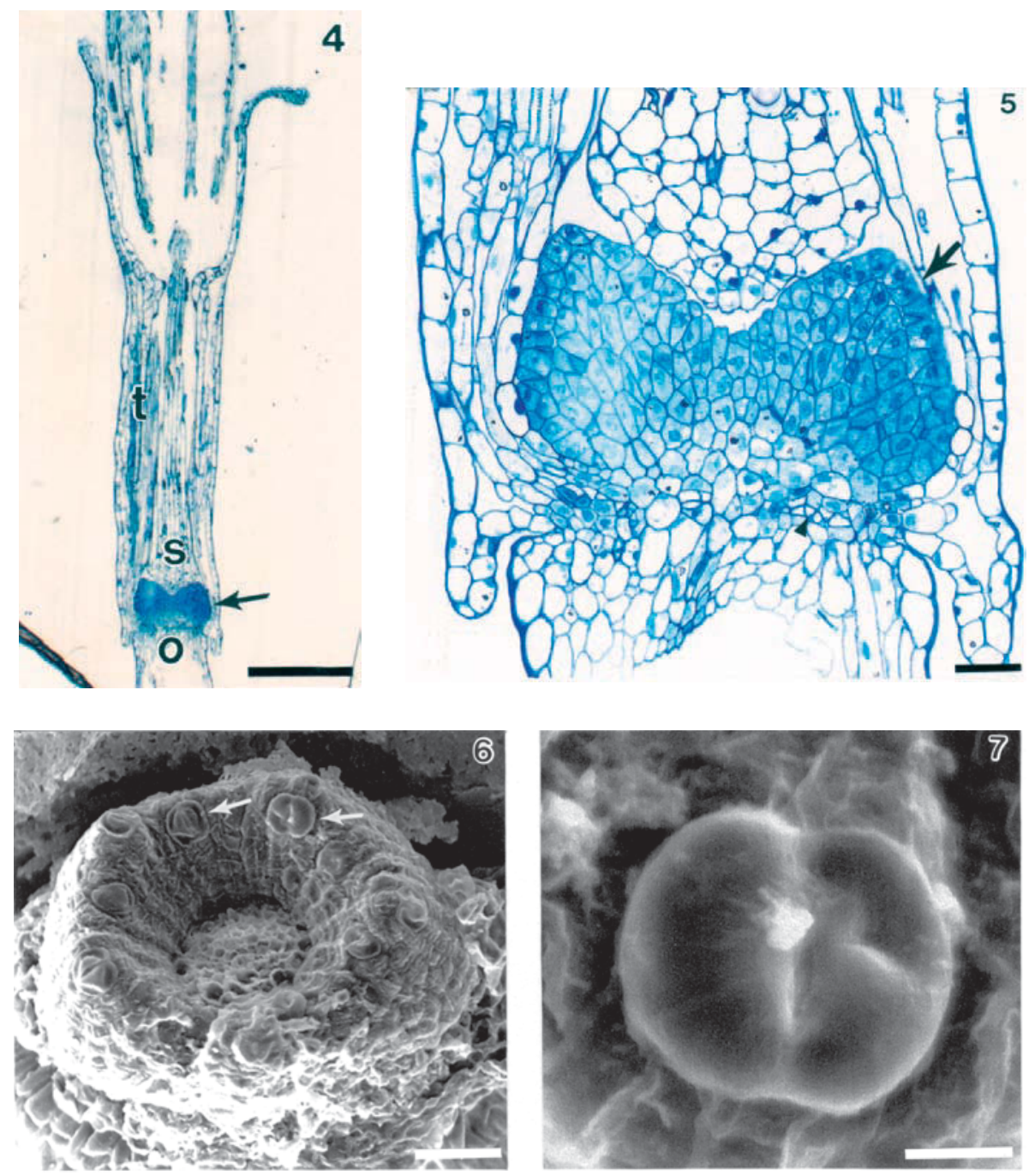

Figs 4 7. Structure of nectary in disk flowers of Achillea millefolium.

Fig. 4. Portion of the longitudinal section of floret with visible nectary (arrow); t corolla tube, s pistil style, o ovary, bar $=400 \mu \mathrm{m}$.

Fig. 5. The nectary on the longitudinal section of floret (arrow). At the base of the nectariferous tissue visible vascular bundles (arrowhead), bar $=50 \mu \mathrm{m}$.

Fig. 6. Scanning electron micrograph of the nectary with visible stomata (arrows), bar $=30 \mu \mathrm{m}$.

Fig. 7. Stona on the nectary surface, bar $=5 \mu \mathrm{m}$. 

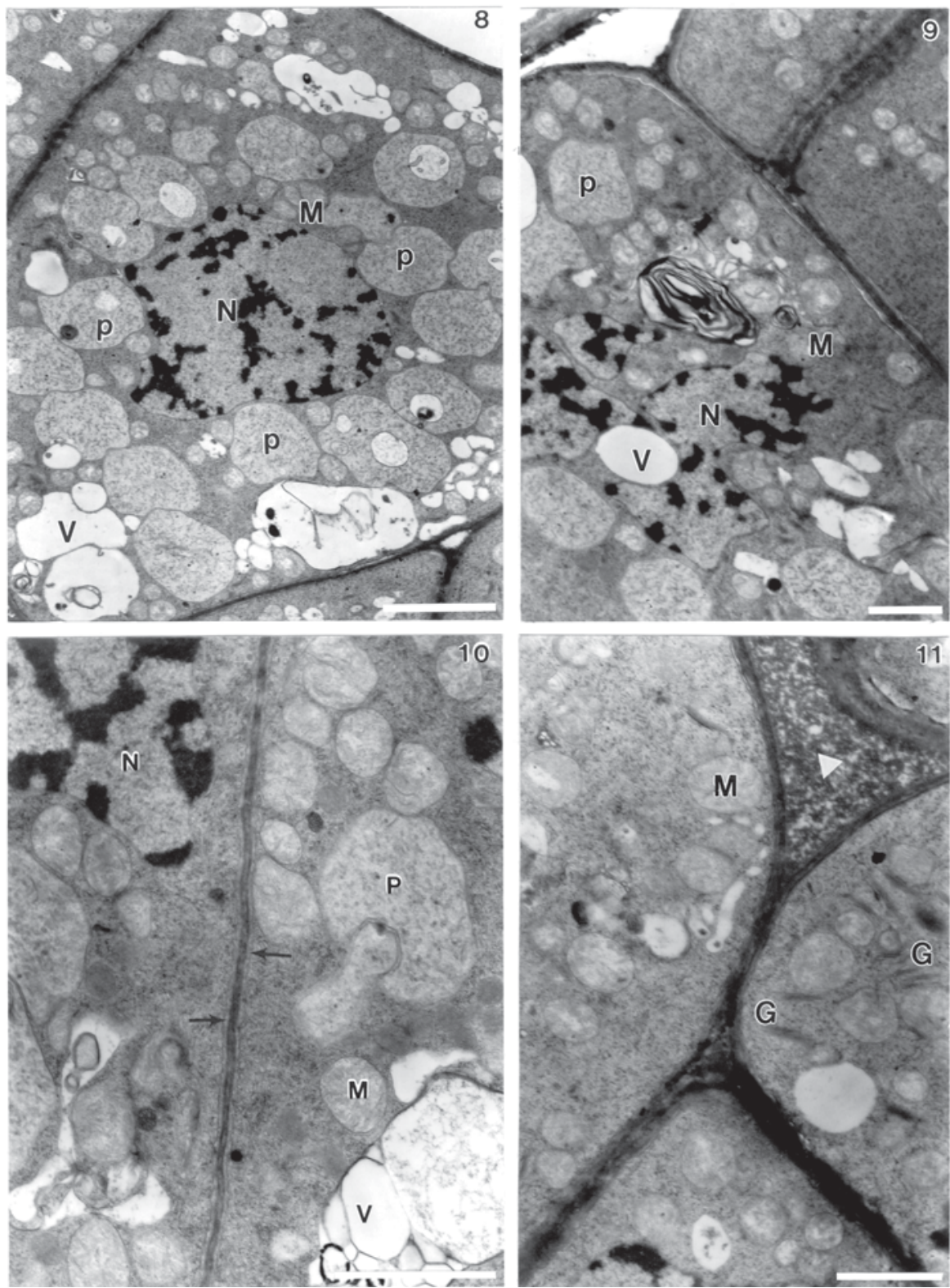

Figs 8 10. Ultrastructure of epidermal cells of the nectary of Achillea millefolium (TEM).

Figs 8 10. Fragments of epidermal cells of the nectary with lobate nucleus $(\mathrm{N})$, numerous plastids $(\mathrm{P})$, mitochondria $(\mathrm{M})$ and numerous small vacuoles $(\mathrm{V})$ containing different deposits. Arrows indicate the periplasmic space adjacent to the cell wall; fig. 8 bar $=5 \mu \mathrm{m}$, fig. 910 bar $=2 \mu \mathrm{m}$.

Fig. 11. Parts of glandular cells with mitochondria (M), Golgi complexes (G) and ribosomes. Arrowhead shows intercellular space filled with fibrillar material, bar $=2 \mu \mathrm{m}$. 
Table 1

Some features of corolla and nectary structure in Achillea millefolium flowers.

\begin{tabular}{|c|c|}
\hline Studied features & Results of measurement \\
\hline Length of corolla of flower $(\mathrm{mm})$ & 2,2 \\
\hline Length of corolla tube of flower $(\mathrm{mm})$ & 1,5 \\
\hline Height of nectary $(\mu \mathrm{m})$ & 181,5 \\
\hline External diameter of nectary $(\mu \mathrm{m})$ & 299,4 \\
\hline Number of gland cells layers & 6,3 \\
\hline Height of epidermis cells $(\mu \mathrm{m})$ & 22,4 \\
\hline Size of gland cells $(\mu \mathrm{m})$ & 27,0 \\
\hline Size of stomata $(\mu \mathrm{m})$ & 38,5 \\
\hline
\end{tabular}

In the species studied, nectar was secreted through the modified stomata located on the surface of the nectary tissue. The guard cells were marked by much larger dimensions compared to other cells of the epidermis, and they were kidney-shaped and a bit elevated above the surface of other cells of the epidermis (Fig. 6). The largest number of the stomata was situated in the upper part of the nectary on its edge. In the material observed, pores of the stomata of the nectary were closed (Figs 6, 7), what was probably attributable to the early development phase of the flowers. The width of the stomata was 36-41 $\mu \mathrm{m}$ (Tab. 1).

Large, often lobate nuclei and very numerous accompanying plastids were observed in the cells of the nectary epidermis through the transmission electron microscope (Figs 8, 9). The organelles which occurred with great frequency also included mitochondria and vacuoles with fibrous contents, secretion vesicles and myelin structures (Figs 8, 9, 10). The plasmalemma had characteristic folds, and it was often located at a certain distance from the wall (Fig. 10). The presence of the periplasmic space may indicate the apoplastic transport of substances comprising nectar.

The secretory cells of the nectaries were characterised by the electron dense cytoplasm and the presence of numerous Golgi complexes and mitochondria with a clearly visible system of cristae (Fig. 11). Abundantly occurring free ribosomes and ribosomes bound to endoplasmic reticulum profiles were located in the cytoplasm. The network of endoplasmic reticulum structures was very extensive. It surrounded nuclei, plastids and other cell organelles, and it concentrated in the vicinity of the cell wall. The walls of the observed cells were electron dense and thickened to a different degree. Dark fibrous secretion occurred in the small intercellular spaces (Figs 11-14). Variously shaped vacuoles were observed in the glandular cells (Fig. 14). 

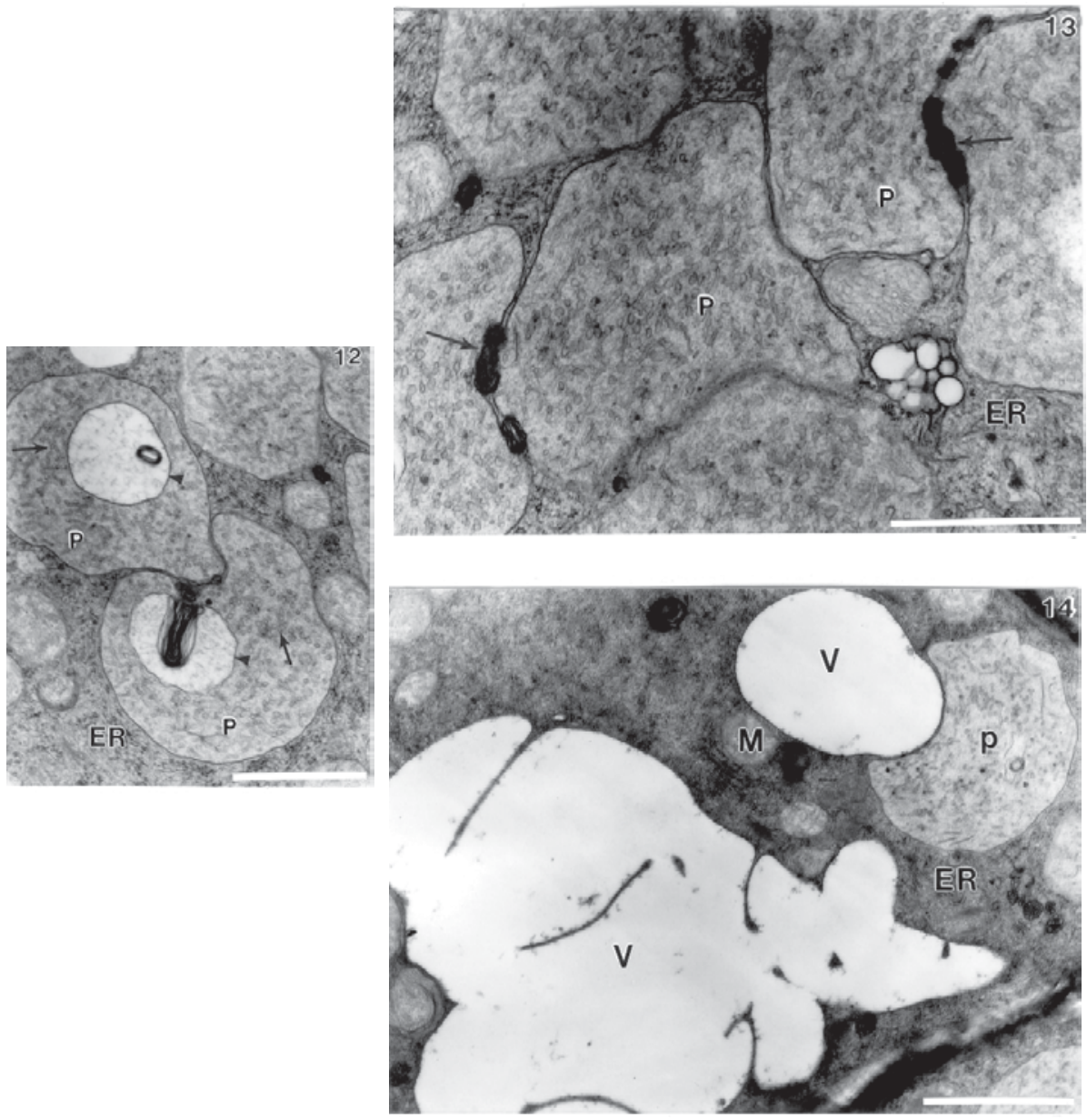

Figs 12 14. Ultrastructure of glandular cells of the nectary.

Fig. 12. Association of plastids with adjacent membranes. The stroma of plastids shows tubules filled with deposits (arrows) and electron transparent areas with fibrous material (arro wheads). Plastids are surrounded with well developed rough ER, bar $=2 \mu \mathrm{m}$.

Fig. 13. Numerous plastids $(\mathrm{P})$ in compact configuration surrounded by tubules of endoplasmic reticulum (ER). In intermembranal space of plastidal envelope and between the plastids envelopes osmiophilic material is observed (arrows), bar $=2 \mu \mathrm{m}$.

Fig. 14. Variform vacuoles (V), plastids (P), mitochondria (M) and well developed cisternae of endoplasmic reticulum (ER), bar $=2 \mu \mathrm{m}$. 
The numerously present organelles were plastids, which can be described as ameboidal on account of the variety of their shapes. In the plastids, tubules filled with contents of different electron density occurred, as well as bright, spherical formations surrounded with a membrane and containing fibrous material and myelin structures (Figs 12-14). Osmophilic material accumulated in the space between the two membranes of the plastid envelope (Fig. 13). The plastids situated next to one another often formed clusters, joined by the membranes, and they, as it were, penetrated one another (Figs 12-13). Similar combinations were also observed in the relation of the plastid with the vacuole (Fig. 14). Clusters of the osmophilic substance could also be seen between the plastids (Fig. 13).

\section{DISCUSSION}

In the study presented, it was found that the Achillea millefolium nectaries were located only in disk flowers at the bottom of the corolla tube, surrounding the base of the pistil style. A similar position of nectaries in species from the Centaurea genus, in Helianthus annuus and Silphium perfoliatum, was described by G u ly ás and Pesti (1966), S a m m a ta ro et al. (1985) and W róblew s k a (1997).

Literature shows that the height of nectary glands in other representatives of the Asteraceae family was as follows: 0.6-1.8 $\mathrm{mm}$ for Centaurea (Gu ly á s and P e s t i , 1966) and 200-360 $\mu \mathrm{m}$ for Helianthus annuus (S a $\mathrm{m} \mathrm{m}$ a t a r o et al., 1985). In the case of the width of the gland in Helianthus annuus flowers, these values were 470-800 $\mu \mathrm{m}$ (S a m mat a ro et al., 1985). The dimensions of the nectaries of the species investigated in the study were smaller $(182 \times 300 \mu \mathrm{m})$ than data presented by the abovementioned authors for other species from this family. Taking into account large differences in the size of flowers of the species compared, it can be stated that the nectaries which occur in very small Achillea millefolium flowers are little smaller than those in much larger Helianthus annuus flowers.

The nectaries of the yarrow were made up of single-layered epidermis and, on the average, 6 layers of secretory cells with smaller dimensions compared to cells of the adjacent tissues. S a m matro et al. (1985), as well as Gulyás and Pesti (1966), demonstrated a larger number of glandular cells in the nectaries of the sunflower and cornflower compared to the Achillea millefolium nectaries. The nectary tissue observed in yarrow flowers was characterised by the presence of small intercellular spaces which were often filled with fibrous material, what was not described in other species from the Asteraceae family. It indicates the apoplastic transport of nectar inside the gland.

No vascular bundles were observed in the secretory tissue area of the yarrow nectaries. Gulyás and Pesti (1966) also found the absence of bundles in the nectaries of several species from the Centaurea genus, whereas in other species of the cornflower, xylem elements made up the nervation of the glands. In the case of the sunflower, the nectaries are supplied through phloem bundles. Phloem elements reached the epidermis, and their ends were observed near the stomata (S a m m a t a ro et al., 1985). 
It is known from literature that a frequent way of nectar release is stomatal secretion (O'Brien et al., 1996; Nepi et al., 1996; Fahn and Shimony, 2001; Wery s z k o- C h mi e lew s k a, 2000; Wer y s z k o- C h mi e le w s k a et al., 2003). The stomata in the yarrow nectaries were elevated above the surface of other cells of the epidermis. It was similarly in the sunflower ( $\mathrm{S}$ a $\mathrm{m} \mathrm{m}$ a t a ro et al., 1985), whereas in the cornflower, the stomata were at one level with other cells of the epidermis ( G u l y á s and P e s t i 1966). In the case of the yarrow, the stomata were of substantial dimensions, much larger than the size of other cells of the epidermis of this gland. The values relating to the width of the stomata studied $(36-41 \mu \mathrm{m})$ proved to be comparable with literature data for species from the cornflower genus $(20-45 \mu \mathrm{m})$ (Gulyás and Pest i, 1966) and for the sunflower $(24-45 \mu \mathrm{m})(\mathrm{S}$ a m m a t a ro et al., 1985). The pores of the stomata observed in the yarrow nectaries were closed. It is probably attributable to the early development phase of the flowers or may indicate stomata movements. Tóth et al. (2000) mentions the process of the rhythmic opening and closing of the stomata in the apple nectaries.

The examination conducted in the TEM showed that the glandular cells of the nectaries had features distinguishing secretory cells. In the numerous plastids observed, spherical structures filled with fibrous material and tubules containing osmophilic secretion of different electron density occurred. The osmophilic substance also accumulated in the space between the two membranes of the plastid envelope. The osmophilic structures in cells of the nectaries of species from other families were also described by other researchers (Fahn and S himony, 2001; S t piczyńs ka et al., 2003). However, no information was found on the abundance of tubules within the plastid stroma. The secretory cells of the species studied had a well-developed network of rough endoplasmic reticulum profiles, which, as F a h n (1979) states, is a characteristic feature of nectary cells. Numerous mitochondria with a well-developed system of cristae were present in the secretory cells of the nectaries observed in the study. Mitochondria also occurred abundantly in the nectaries of other species from diffarent families (O' Brien et al., 1996; Fahn and Shimony, 2001; Stpic z y ń s k a et al., 2003). Golgi complexes, in which, as F a h n (1979) states, nectar can be stored, were structures characterised by their large number in the studied nectary cells of the yarrow. The presence of the active ER, mitochondria and Golgi complexes are characterised by granulocrine nectar secretion ( $\mathrm{R} \mathrm{a} \mathrm{c} \mathrm{h} \mathrm{mile} \mathrm{vitz} \mathrm{and} \mathrm{Fah} \mathrm{n,}$ 1973), which presumably occurs in the species studied.

\section{REFERENCES}

F a h n A., 1952. On the structure of floral nectaries. Bot. Gaz. 113: 464470.

F a h n A., 1979. Ultrastructure of nectaries in relation to nectar secretion. Amer. J. Bot. 66 (8): 97985.

Fahn A., Shimony C., 2001. Nectary structure and ultrastructure of unisexual flowers Ecbalium elaterium (L.) A. Rich. (Cucurbitaceae) and their presumptive pollinators. Ann. Bot. 87: 2733.

Gu ly á s S., Pe s t i J., 1966. Angaben zur Anatomie der Nektarien der Centaurea. Acta Biol. Szeged, XII, (1 2): 1724. 
J a błoń s k i B., 1998. Wiadomości z botaniki pszczelarskiej. W: Pszczelnictwo, pod red. J. Prabuckiego. Wyd. "Albatros", Szczecin.

Ne p i M., C i m polin i F., P a c in i E., 1996. Development and ultrastructure of Cucurbita pepo nectaries of male flowers. Ann. Bot. 78: 95104.

O ' B r i e n S. P., L o ve y e s B. R., G r a n t W. J. R., 1996. Ultrastructure and function of floral nectaries of Chamelaucium uncinatum (Myrtaceae). Ann. Bot. 78: 189196.

Rachmilevitz T., Fahn A., 1973. Ultrastructure of nectaries of Vinca rosea L., Vinca major L. and Citrus sinensis Osbeck cv. Valencia and its relation to the mechanism of nectar secretion. Ann. Bot. 37: 19.

S a m m a t a ro D., Er i cks on E. H., G a r m e n t M. B., 1985. Ultrastrucure of the sunflower nectary. J. Apic. Research, 24 (3): 150160.

S t p i c z y ń s k a M., D a vi e s K. L., G reg g A., 2003. Nectary structure and nectar secretion in Maxillaria coccinea (Jacq.) L. O. Williams ex Hodge (Orchidaceae). Ann. Bot. 93: 8795.

S m e t s E., 1986. Localization and systematic importance of the floral nectaries in the Magnolia tae (Dicotyledons). Bull. Jard. Bot. Nat. Belg. 56: 5176.

Tóth E. N., B u bán T., Heves i M., Oros z Kovaćs Z., S z abó L.G., 2000. Morpho logical characteristics of the nectary and composition of nectar in flowers of selected apple cultivars. Acta Hort. 538: 301308.

W róblew ska A., 1997. Badania wartości pszczelarskiej Silphium perfoliatum L. Mat. I Ogólnopolskiej Konferencji Naukowej pt. „Biologia kwitnienia, nektarowania i zapylania roślin”. Lublin, 13 14. 11: 5965.

Wery s z k o Ch mi e lew s k E., 2000. Ecological features of flowers including nectary struc ture of chosen species from Lamiaceae family. Pszcz. Zesz. Nauk., XLIV (2): 223232.

Weryszko Chmielewska E., Masierowska M. L., Konarska A., 2003. Cha racteristics of floral nectaries and nectar in two species of Crataegus (Rosaceae). Plant. Syst. Evol. 238: 3341 .

\section{Morfologia, anatomia i ultrastruktura nektarników kwiatowych krwawnika pospolitego (Achillea millefolium L.)}

\section{Streszczenie}

Badano cechy morfologiczne i anatomiczne oraz związane z ultrastrukturą komórek nektarników Achillea millefolium z rodziny Asteraceae. Obecność nektarników stwierdzono tylko w kwiatach rurkowatych u podstawy szyjki słupka. Zbadano mikromorfologię nektarników w SEM, przeprowadzono obserwacje struktury w mikroskopie świetlnym i transmisyjnym elektronowym. Określono liczbę warstw budujących gruczoł, wielkość oraz kształt komórek epidermy i komórek gruczołowych. Analizowano ultrastrukturę komórek wydzielniczych.

Dyskoidalny gruczoł nektarnikowy oglądany z góry miał kształt pięciokąta

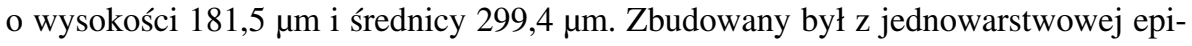
dermy oraz średnio z 6 warstw komórek wydzielniczych. Komórki gruczołowe były większe $(27 \mu \mathrm{m})$ od komórek skórki $(22 \mu \mathrm{m})$, różny był także kształt komórek w obu tkankach. Sekrecja nektaru odbywała się przez zmodyfikowane aparaty szparkowe. 
Komórki aparatów szparkowych były wyniesione ponad powierzchnię pozostałych komórek tkanki okrywającej oraz wyróżniały się większymi rozmiarami. Nektarniki zaopatrywane były przez wiązki waskularne biegnące od szyjki słupka, które kończyły się u podstawy nektarnika, nie wnikając w głąb gruczołu.

Badane w TEM komórki epidermy nektarnika krwawnika charakteryzowały się obecnością dużych jąder komórkowych, licznych plastydów, mitochondriów oraz wakuol z depozytami włóknistej wydzieliny oraz pęcherzykowatymi strukturami. W komórkach tkanki wydzielniczej nektarnika obserwowano elektronowo gęstą cytoplazmę, liczne plastydy, mitochondria, aparaty Golgiego oraz rozległą sieć retikulum endoplazmatycznego. 